NBER WORKING PAPER SERIES

\title{
LABOR SUPPLY EFFECTS OF THE EARNED INCOME TAX CREDIT: EVIDENCE FROM WISCONSIN'S SUPPLEMENTAL BENEFIT FOR FAMILIES WITH THREE CHILDREN
}

\author{
Maria Cancian \\ Arik Levinson \\ Working Paper 11454 \\ http://www.nber.org/papers/w11454 \\ NATIONAL BUREAU OF ECONOMIC RESEARCH \\ 1050 Massachusetts Avenue \\ Cambridge, MA 02138 \\ June 2005
}

The authors are grateful to the Association for Public Policy and Management (APPAM) for support through the NSAF Small Research Grants Program, to Sjamsu Rahardja and Emma Nicholson for research assistance, to Elizabeth Evanson and Dawn Duren for assistance in preparing this manuscript, and to Karl Scholz for helpful discussions. The views expressed herein are those of the author(s) and do not necessarily reflect the views of the National Bureau of Economic Research.

(C)2005 by Maria Cancian and Arik Levinson. All rights reserved. Short sections of text, not to exceed two paragraphs, may be quoted without explicit permission provided that full credit, including (C) notice, is given to the source. 
Labor Supply Effects of the Earned Income Tax Credit: Evidence from Wisconsin's Supplemental Benefit for Families With Three Children

Maria Cancian, Arik Levinson

NBER Working Paper No. 11454

June 2005

JEL No. H24, H73, J38

\section{$\underline{\text { ABSTRACT }}$}

We examine the labor market consequences of the Earned Income Tax Credit (EITC), comparing labor market behavior of eligible parents in Wisconsin, which supplements the federal EITC for families with three children, to that of similar parents in states that do not supplement the federal EITC. Data come from the 2000 Census of Population. Most previous studies have relied on changes in the EITC over time, or EITC eligibility differences for families with and without children, or have extrapolated from measured labor supply responses to other tax and benefit programs, and find significant effects of the EITC on employment. In contrast, our cross-state comparison examines a larger difference in EITC subsidy rates, uses more similar treatment and control groups, relies on a policy that has been in place for 5 years, and finds no effect of the EITC on employment or hours worked.

Maria Cancian

University of Wisconsin 1225 Observatory Drive Madison, WI 52706

cancian@1afollette.wisc.edu

Arik Levinson

Department of Economics Georgetown University

ICC 571

Washington, DC 20057-1036

and NBER

am16@georgetown.edu 


\section{Labor Supply Effects of the Earned Income Tax Credit: Evidence from Wisconsin's Supplemental Benefit for Families with Three Children}

The Earned Income Tax Credit (EITC) is the largest federal means-tested antipoverty program in the United States. Federal EITC tax expenditures in 1999 were \$31 billion, almost as much as for the Food Stamp and Temporary Assistance for Needy Families (TANF) programs combined. Nearly 19 million federal tax returns claimed the EITC, while 6 million people participated in TANF and 18 million received food stamps. ${ }^{1}$

In 1999, families with two children could receive a refundable 40 percent federal income tax credit for each dollar of earned income up to $\$ 9,540$. Taxpayers earning between $\$ 9,540$ and $\$ 12,460$ received the maximum possible federal credit of $\$ 3,816(0.40$ times $\$ 9,540)$. Beyond $\$ 12,460$, each dollar of earnings reduced the EITC by 21.06 cents. In addition, 15 states offer supplemental tax credits based on the federal EITC. ${ }^{2}$

What does the U.S. government receive for this expenditure? Two goals are typically ascribed to the EITC: (a) to redistribute income to working poor families, and (b) to encourage labor supply. While the first is unambiguously achieved, the second is theoretically and empirically less certain.

This paper measures the labor supply consequences of the EITC, using data from the 2000 U.S. Census of Population and focusing on Wisconsin's supplement to the federal EITC for families with three or more children. While numerous empirical studies of the EITC's labor market consequences exist, most examine changes in the federal rate over time. In many cases these changes are fairly small. For example, Eissa and Liebman (1996) investigate the 1987

\footnotetext{
${ }^{1}$ Council of Economic Advisers (2001).

${ }^{2}$ Johnson (2000).
} 
expansion of the federal EITC from 11 to 14 percent. In contrast, a three-child family in Wisconsin receiving the EITC will receive a tax credit that is 17 percentage points larger than that received by a comparable family in a state with no supplemental credit. More recent studies of EITC changes gradually phased in during the 1990s face the additional challenge of separating the effect of the EITC from general time trends. Finally, some previous studies rely on comparisons of women with and without children. In contrast, we use Wisconsin's EITC supplement to study women with two and with three children, which we argue are more comparable groups.

\section{Theory}

The simplest theoretical effects of the EITC on labor supply, abstracting from other sources of income, are well known and can be summarized by the static labor supply diagram in figure $1 .^{3}$ A person not working earns zero income, and the slope of the solid diagonal budget line is the wage. The dotted line in figure 1 depicts the sum of earned income and the EITC, and so its slope along segment $\mathbf{A}$ is 1.4 times the wage rate. At earned income of $\$ 9,540$ in 1999 the federal EITC is capped, and the dotted budget segment $\mathbf{B}$ runs parallel to the original budget line. Above \$12,460, tax credits are reduced by 21.06 cents for every dollar earned, and so the slope of the dotted line $\mathbf{C}$ is 0.7894 times the wage rate.

The effects of this tax program on labor supply can be broken into two parts: (a) employment, the decision whether or not to work at all, and (b) the number of hours to work. The first effect on employment is theoretically unambiguous. Any single parent who would

\footnotetext{
${ }^{3}$ This discussion assumes continuous labor supply, that people can choose to work as few or as many hours as they like, and therefore may overstate actual labor supply responses to employment subsidies like the EITC.
} 
choose to work in a world without the EITC will also choose to work in an otherwise identical world with an EITC. ${ }^{4}$ On the other hand, some individuals not working in the absence of the EITC will prefer to work if there is an EITC. The indifference curve depicted in figure 1 illustrates such a case. Note that in this simple case we assume workers can choose any number of hours, and only the initial subsidy rate matters for employment, not the size of the phase-in range.

Even the slightest departure from the simplest static, continuous-hours case muddies this employment effect. If there are fixed costs of working (childcare, commuting, etc.), then the size of phase-in range does matter for employment. Figure 2 depicts the labor-leisure budget for a worker facing fixed employment costs. With the depicted indifference curve, the worker will choose not to work under the original (solid) EITC, and will chose to work under an expanded (dashed) EITC with the same subsidy rate but a larger phase-in range. Still, the theoretical effect of the EITC on employment is unambiguously positive.

The second effect, on hours worked, is ambiguous even in the simplest case depicted back in figure 1. Along segment $\mathbf{A}$ the EITC increases the after-tax wage rate (by 40 percent for parents with two children), with offsetting income and substitution effects. At $\mathbf{B}$, workers effectively receive a lump-sum transfer (of \$3,816 in 1999 for families with two children), with pure income effects that unambiguously decrease desired work hours. At $\mathbf{C}$, in the phase-out range of the EITC, workers receive a lump-sum transfer plus a decrease in the after-tax wage rate. Both the income and substitution effects unambiguously decrease desired hours.

\footnotetext{
${ }^{4}$ See Eissa and Hoynes (1998) for an analysis of the EITC and the labor supply of married couples, where this simple employment rule does not hold.
} 
Collectively, the labor market incentives of the EITC are mixed. The program has unambiguously positive theoretical effects on employment, but conditional on employment the program has largely negative effects on hours worked.

Finally, there are reasons to believe that all of these effects will be muted by complexities and lags in the tax code. Employment may only be offered in discrete quantity categories (e.g. part-time 20 hours per week or full-time 40 hours). Tax credits for income earned in one year are not received until taxpayers' EITC forms are filed in the following year. ${ }^{5}$ Workers' limited understanding of the EITC may also reduce their responsiveness. ${ }^{6}$ For all of these reasons, the size of the actual effect of the EITC on labor supply is an empirical question.

\section{Previous Studies}

Most existing work on the EITC relies on changes in the program's benefits, especially the 1987 and 1993 expansions. So as not to confound the effects of the EITC expansions with other changes in labor market conditions, these studies typically contrast changes in labor market behavior of eligible taxpayers before and after the EITC expansion to that of ineligible taxpayers. Eissa and Liebman (1996), for example, compare the labor supply of single mothers to that of single women without children. Meyer and Rosenbaum (2000) compare single mothers to single childless women, married women, and black men. These differences-in-differences strategies assume that any changes in labor market conditions that occur simultaneously with increases in EITC benefits do not affect single mothers and the comparison groups differently.

\footnotetext{
${ }^{5}$ Although some taxpayers can receive advanced EITC payments through their employers, only 1 percent of EITC recipients participated in this program in 1998 (Hotz and Scholz, 2001).

${ }^{6}$ See Ross Phillips (2001) for a discussion of workers' knowledge of the EITC.
} 
A second feature of these approaches is that the comparison groups typically have very high labor force participation. Of the women with no children that Eissa and Liebman use as a control group, 95 percent were working at the time of the 1987 EITC expansion. Any general increase in labor force participation, therefore, is much more likely to be experienced by the women with children, of whom only 75 percent were working. Meyer and Rosenbaum restrict their sample to those with no more than a high school education, where labor force participation rates are lower and these ceiling effects are less important.

Another set of empirical papers has attempted to estimate more structural models of labor supply as a function of the after-tax wage, and then used the EITC's various phase-ins and phaseouts to predict labor supply responsiveness to the EITC specifically. This approach assumes that administrative differences between the EITC and other tax provisions (such as the fact that the EITC credit is not realized until tax forms are filed the following year) do not affect labor supply responsiveness.

In a recent paper, Meyer and Rosenbaum (2001) estimate a structural model of labor supply in an effort to estimate the effects of the EITC as well as other policies targeting lowincome families, including AFDC, Food Stamps, Medicaid, and child care and training programs. In their preferred specification they find that employment is responsive to changes in total taxes. They include all single women, allowing the effects of taxes to be identified through differences between women with and without children. They also estimate the model on a sample that includes only single mothers, with identification resting on differences across states and numbers of children. In this case the estimated effects are substantially smaller, and are only significant using one of two data sources. 
Neumark and Wascher (2001) estimate the effect of changes in the EITC on changes in employment, earned income, and official poverty status-the focus of their analysis. They match March CPS files from 1986 to 1995 in two-year pairings in order to observe changes in labor supply and earned income for individual families. Among families with no worker in the first year, increases in the EITC are associated with increased employment in the second year. However, among families with a worker in the first year, increases in the EITC are associated with declines in total hours worked. ${ }^{7}$

In general, these studies tend to find small negative effects of EITC expansions on hours worked, and large positive effects on employment. For example, Eissa and Liebman find a statistically insignificant effect on hours worked, and a 2.8 percentage point increase in employment for single parents. Meyer and Rosenbaum (2001) conclude that 62 percent of the increase in single mothers' employment between 1984 and 1996 was due to the EITC-although the estimated effect falls by about half when using the estimates from the specification using only single mothers.

Hotz and Scholz (2001) argue that "probably the most powerful way to look at EITC labor market effects is to look at differences in labor market patterns for families with one and two-or-more children starting in the mid 1990s (when the discrepancies began to get large)." Hotz, Mullen and Sholz (2002) do that by examining the 1994 expansion of the federal EITC from 18.5 percent to 34 percent for families with one child, and from 19.5 percent to 40 percent for families with two or more children. They note that the difference between the EITC for 1 and 2-child families increased from 1 percentage point (19.5 minus 18.5 percent) to 6 percentage

\footnotetext{
${ }^{7}$ One puzzling aspect of Neumark and Wascher's results is that they sometimes find positive effects of state EITC credits on employment, but negative effects of the federal EITC on employment.
} 
points (40 minus 34), and that controlling for other family characteristics this difference was associated with a 6 percent increase in employment. The employment elasticity they estimate (1.2) falls at the high end of previous estimates.

A second study that exploits the change in family-size differences in EITC benefits is Grogger (2003a). That paper uses data from the March CPS each year from 1979 to 2000. It regresses welfare use, employment status, and weeks worked on policy variables, time, state and family size dummies, and the federal EITC maximum credit, which varies over time and across family sizes starting in 1991. Grogger finds that a \$1000 increase in the maximum federal EITC credit increases employment by 3.6 percentage points and increases weeks worked per year by 1.2 weeks.

\section{Wisconsin's EITC Supplement}

We take the Hotz et al. (2002) and Grogger (2003a) strategy one step further by looking at the even larger differences in EITC subsidy rates provided by Wisconsin's third-child supplement. Wisconsin provides the largest state EITC supplement, and the only one that differentially affects families with three children. Since 1995, Wisconsin has supplemented the federal EITC by 4 percent for families with one child, 14 percent for families with two children, and 43 percent for families with three children, where the Wisconsin supplement is calculated as the relevant fraction of the federal credit. Consider, for example a single parent with three children in Wisconsin earning $\$ 9540$ in 1999 . She would be eligible to receive the maximum federal EITC credit of $\$ 3816$ (40 percent), and a state credit of another $\$ 1641$ (43 percent of the 
federal credit). An otherwise identical parent in Ohio, or Indiana, or any of the 35 states that do not have their own EITC programs, would receive only the federal credit of $\$ 3200$.

The Wisconsin supplement rate (17.2 percentage points in this case-43 percent times 40 percent), is larger than the entire federal EITC subsidy rate when Eissa and Liebman examined the expansion in 1987 from 11 to 14 percent, and three times as large as the 5 percentage point difference used by Hotz, et al. and Grogger. Even when we subtract Wisconsin mothers' twochild benefit (45.6 percent) from Wisconsin's three-child benefit (57.2 percent), that difference (11.2 percentage points) is twice as large as the difference exploited by Hotz et al. and Grogger, and three times that of Eissa and Liebman.

If we focus on the maximum benefit, rather than the subsidy rate, the Wisconsin thirdchild supplement is comparable in magnitude to policy differences studied previously. Eissa and Liebman study the 1987 EITC expansion, when the maximum federal benefit increased by $\$ 301$. Hotz et al., and Grogger study the 1990's family size changes, where the difference between one and two-child families increased from \$0 in 1990 to \$1404 in 1996. By comparison, the 1999 Wisconsin EITC benefit for three-child families was \$1641 larger than for three-child families in other states, and \$1107 larger than for two-child families in Wisconsin.

Finally, we believe that an advantage of our approach is that we can use cross-sectional differences to identify the EITC effect. Prior studies have relied on changes in EITC subsidy rates that have been phased in over time, and eligible workers may take several years to learn about and respond to the new policies. Estimates relying on changes in differences over time likely have serial correlation in the error terms, which can generate spurious significant estimated effects of ineffective policies (Bertrand, et al. 2002). By using cross-state variation we 
avoid this bias. Wisconsin's 43 percent EITC supplement has been in place since 1995, long enough for us to interpret data from the 2000 Census as an equilibrium response to the policy differences we study. ${ }^{8}$

The actual size of the Wisconsin supplement is depicted in figure 3. Most papers on the EITC contain a figure similar to figure 1, where the vertical axis is exaggerated for the sake of exposition. Instead, figure 3 displays the actual federal EITC and the Wisconsin supplements on a set of axes that are not exaggerated. The Wisconsin supplement, though noticeable on the graph, is not dramatic. It seems plausible to us that the budget differences depicted in figure 3, received as lump sums the following year, might have no effect on labor supply.

Because we need a large sample of poor single mothers in Wisconsin, we use as data for this study the 5-percent Public Use Microdata Sample (PUMS) of the 2000 US Census of population.

Table 1 begins to sketch the empirical strategy we use to identify the labor market effects of the EITC, in a simple differences-of-means framework without controlling for other demographic characteristics of families or other state policy differences. Table 1A presents the employment rates for single women aged 19 to 44, with incomes below 300 percent of the federal poverty line. ${ }^{9}$ (The construction of our sample is described in appendix table A1.) We show results for two measures of employment status: current employment, and whether the respondent worked at any time last year. As discussed above, the EITC has a theoretically

\footnotetext{
${ }^{8} \mathrm{We}$ do, of course, appreciate the irony of touting the benefits of not having panel data.

${ }^{9}$ Some readers expressed concern that by focusing on low-income mothers, we select on an endogenous variable. Below we test the sensitivity of our results by using instead mothers with low education. (See the final panel of table 3).
} 
unambiguous positive effect on the decision to work, but has ambiguous effects on total hours worked. The clearest test of the effect on the decision to work is therefore an analysis of any work in a given year, since a change in hours may result in changes in hours worked in a given week, or in the weeks worked in a given year. (The EITC is calculated with reference to annual earnings.) On the other hand, a very high proportion of mothers work at some point during the year, potentially leaving less room to observe an EITC effect on employment. ${ }^{10}$

Low-income single mothers in Wisconsin with two children were eligible for up to a 45.6 percent tax credit on earnings (40 percent federal credit plus 14 percent state supplement, where the state supplement is a fraction of the federal credit). The first column of table 1A shows that 77 percent of this group was working at the time of the census. By contrast, working single parents with three children in Wisconsin were eligible for up to a 57.2 percent credit (40 percent federal credit plus 43 percent state supplement), and 73 percent of this group worked at the time of the census. Though the difference $(-0.043)$ seems to suggest that the EITC supplement for three children discourages employment, we must recognize the unequal private work incentives for two-child and three-child families.

To provide a basis for comparison, the second row of table 1A examines employment rates for similar families in states that do not supplement the federal EITC. Employment in those states is lower than in Wisconsin by 8 or 9 percentage points. More importantly, in states without an EITC supplement, mothers with three children are 6 percentage points less likely to work than mothers with two children. The smaller difference between the employment rates in row 1 ,

\footnotetext{
${ }^{10}$ Meyer and Rosenbaum (2001: 1082) argue that a measure of current employment (in their case, whether a woman worked in the last week) is more policy relevant, since it gives a measure of the proportion of all women working at a given time.
} 
where having a third child increases the EITC from 14 to 43 percent of the federal level, than in row 2, where a third child adds nothing to the EITC, is consistent with Wisconsin's EITC supplement increasing employment for eligible parents with three children by 1.8 percentage points, though that difference is statistically insignificant.

The second part of table 1A presents a parallel analysis of employment, in this case considering the proportion of mothers who worked at any time during the previous year. Employment levels by this definition are higher, but the differences by number of children and state are similar. In Wisconsin single mothers with three children were 4.0 percent less likely to work during 1999 than those with two children. In states that do not have an EITC supplement, mothers with three children were 4.4 percent less likely to work. Again the smaller difference between the employment rates in row 1 than in row 2 is consistent with Wisconsin's EITC supplement increasing employment for eligible parents with three children, but also by a small and statistically insignificant amount.

Table 1B conducts the same exercise for hours worked for women who did work. Lowincome working single mothers in Wisconsin with two children worked an average of 37.9 hours per week; working single mothers with three children in Wisconsin worked an average of 38.3 hours per week. (The difference is statistically insignificant.) For comparison, the second row of table 1B examines the average weekly work hours in states without EITC supplements. On average, low-income single working women with two children in such states worked 38.0 weekly hours, while women with three children worked 37.7 hours. One interpretation of these results would be that without the third-child EITC supplement, working Wisconsin mothers would have worked fewer hours. Mothers in Wisconsin with three children work more than 
mothers with two children; in other states they work less. However as with the employment results in table 1 , this difference-in-differences (+0.69 hours), is statistically significant.

Tables 1A and 1B do not control for other demographic differences between small and large families or between Wisconsin families and those of other states. Nor do they control for differences among states other than their EITC schedules. For this reason, we have also estimated versions of

$$
Y_{i}=\alpha+\beta_{1}(W I)+\beta_{2}(3 k i d s)+\beta_{3}(W I) *(3 k i d s)+\beta_{4} X_{i}+\epsilon_{i}
$$

where $Y_{i}$ is the outcome of interest (e.g., employment) for household $i$, WI is a dummy variable equal to 1 for households in Wisconsin, 3 kids is a dummy variable for households with three children, and $\boldsymbol{X}_{\boldsymbol{i}}$ are characteristics of households and states, including age, education, health, race, state unemployment rates, and state welfare policies. Including those other characteristics estimates the differential effect of Wisconsin's large third-child supplement while controlling for other important family and policy differences.

One concern with comparing Wisconsin to other states is that there may be some feature of Wisconsin policy or Wisconsin residents that makes labor supply behave differently in that state. By comparing the labor supply of women with two children to that of women with three children in Wisconsin and in comparison states, we ameliorate some of that problem. To the extent that features of Wisconsin's economy or policy environment influence mothers' employment in general, these state-specific effects will not bias our estimates of the difference in employment rates for mothers with two or three children. However, there may be reasons beyond the EITC supplement why having a third child has different effects on labor supply in 
Wisconsin than in the comparison states. Two obvious candidates are state welfare policy and state child care policy.

On both counts, Wisconsin's policies potentially exaggerate the differential labor supply of low-income women with larger families. The first concern is accounting for differences in state AFDC and TANF benefit increases for larger families. Under AFDC, cash benefits increased with family size in every state. With the implementation of TANF, all but a few states continued to pay larger cash benefits to families with more children. In Wisconsin, however, TANF cash benefits do not depend at all on the number of children. If we were to find Wisconsin mothers with three children more likely to work, that result might have been due to the generosity of Wisconsin's EITC supplement or to the lack of a family size adjustment in its cash welfare program. ${ }^{11}$ To account for this, we include in our estimates of equation (1) a measure of maximum state AFDC/TANF benefits.

A second factor that may systematically alter the work incentives of families of different sizes is the availability and cost of subsidized child care. In the absence of subsidized care, families with more young children face higher work-related child care expenses. Wisconsin offers relatively generous child care subsidies and has high rates of subsidized child care use. Since reducing the cost of child care should be particularly important for larger families,

\footnotetext{
${ }^{11}$ There is substantial variation in benefit levels across states, and in the absolute and proportional increase in benefits for larger families. Prior to TANF implementation, median AFDC benefits were \$80 (and 21 percent) higher for families with three children than for those with two. Wisconsin AFDC benefits were \$517 for a family of three and $\$ 617$ for a family of four- a difference of $\$ 100$ (and 19 percent). In 2000, eight states had maximum monthly TANF benefits for families with three children that were at least $\$ 100$ higher than maximum benefits for those with two children. At the same time, fifteen states had benefits for two and three child families that varied by $\$ 50$ or less. While many states with higher overall benefit levels also had greater increases for larger families, the pattern was inconsistent: some states increased benefits for families with a third child by more than 25 percent, while others included adjustments of less than 10 percent. Wisconsin is an extreme case in this regard. Under Wisconsin's TANF program, benefits do not vary with family size: most women qualify for a maximum cash payment of about $\$ 650$, regardless of the number of children.
} 
Wisconsin's child care policy may further exaggerate our estimates of the effect of the EITC supplement on the labor supply of women with more children. Thus, in our estimates of equation (1) we include two measures of the availability and generosity of child care subsidies: total expenditures on child care per poor child under the age of 13, and total preschool and Head Start spending per child under age $6 .{ }^{12}$

While our model includes state and family size-specific measures of cash benefits and child care subsidies, we cannot be confident that our measures perfectly capture the influence of these policies on the labor supply of two and three child families in Wisconsin and other states. To the extent that we fail to fully account for these policies, our estimates of the labor supply effect of the EITC may be upwardly biased- since both child care and cash benefit policies would also create a greater incentive for families with more children to work at higher rates in Wisconsin than in most other states. ${ }^{13}$ In the end, however, none of this will matter. Wisconsin's lack of TANF family size adjustment and generous child care policies will bias our findings in favor of measuring a large EITC effect on labor supply. But in a departure from the published literature to date, we find no EITC effect on labor supply.

Table 2 presents estimates of equation (1). In column 1 we show the means and standard deviations of the control variables for the entire population of working and nonworking single mothers. (Again we limit the sample to women with incomes below 300 percent of the federal

\footnotetext{
${ }^{12}$ We thank Marcia Meyers for providing these state-level measures of child care expenditures. Because these data omit Washington DC and Wyoming, we omit those states from all of the analysis here. We have tried the analyses with DC and WY, and dropping the child care variables, with no discernable change. For a detailed analysis of child care policy and single mothers' employment, see Bainbridge, Meyers, and Waldfogel (2002).

${ }^{13}$ Ellwood (2000) makes this point slightly differently. He notes that state welfare policies will be measured with error, imparting a downward bias on their estimated effects. If state EITC benefits are correlated with state welfare policies, this can impart an upward bias on the estimated EITC effects.
} 
poverty line, having either two children or three children, and living in either Wisconsin or comparison states without EITC supplements.) Columns 2 and 3 contain estimates for a probit regression of current employment, defined as working at the time of the census. Columns 4 and 5 contain estimates for a probit regression of annual employment, defined as having worked in the year prior to the census. Finally, column 6 has results from an OLS regression of weekly hours worked.

Turning to the first row of table 2, we see that 2.1 percent of this sample live in Wisconsin. The Wisconsin mothers are more likely to work and work more weekly hours than their non-Wisconsin counterparts. The probit coefficients suggest that mothers in Wisconsin are 3 to 4 percentage points more likely to be working-either at a point in time, or at some point in the year-than otherwise similar women in the comparison states.

Thirty-one percent of the sample has three children, with the remainder having two children. Women with a third child are less likely to be working at a point in time, or at any time during the year, and work fewer weekly hours. The probit coefficients suggest that having a third child reduces the probability that a single mother works by about 3 percentage points.

The key coefficient is that on the interaction between the Wisconsin dummy and the third child dummy, because only in Wisconsin does the state EITC supplement increase with the addition of a third child. The coefficient on hours worked in column $6,0.58$, is both small and statistically insignificant. This is unsurprising, given the ambiguous theoretical effects of the EITC on labor supply. ${ }^{14}$

\footnotetext{
${ }^{14}$ We have also estimated column (6) as a Tobit, and as a simple OLS including both working and nonworking mothers. In no case is the coefficient on the interaction term large or statistically significant.
} 
The EITC does, however, have unambiguous theoretical effects on employment. The relevant interaction coefficients from columns 2 and 4 of table 2 are small, statistically insignificant and negative: -0.015 for currently employed, and -0.080 for worked last year. These suggest that having a third child in Wisconsin does not increase the probability of working, relative to having a third child in a state without an EITC supplement, and that Wisconsin's large EITC supplement has no effect on labor supply.

\section{Comparisons with Previous Results}

Eissa and Liebman found that women with children increased their employment after the 1987 EITC expansion by 1.9 percentage points. That was in response to an increase in the federal EITC from 11 to 14 percent, or a 2.7 percent increase in the total labor compensation. By contrast, we find a (statistically insignificant) decrease in employment of -0.5 to -2.1 percentage points in response to an 8 percent increase in the EITC. ${ }^{15}$ Roughly speaking, Eissa and Liebman estimate a statistically significant employment elasticity of 0.70 , while our insignificant point estimate of that same elasticity is -0.06 to $-0.26 .{ }^{16}$ Meyer and Rosenbaum (2001:1089-92) estimate that a \$1,000 decline in annual taxes increases employment by 2.7 to 4.5 percentage points, implying elasticities of .83 to 1.07 .

Grogger (2003a) focuses on the maximum EITC benefit, and estimates that a $\$ 1000$ increase in that maximum increases employment by 3.2 percentage points. Hotz et al. (2002)

\footnotetext{
${ }^{15}$ Women with two children in Wisconsin receive a total EITC benefit of 0.456 percent (federal credit of 0.4 plus Wisconsin's 14 percent supplement). Women with three children receive 0.572 percent (the federal credit plus Wisconsin's 43 percent supplement). The ratio 1.572/1.456 equals 1.08.

${ }^{16}$ Hotz and Scholz (2001) report elasticities with respect to net incomes, which relies on an assumption about the typical work hours of a labor market entrant. We report elasticities with respect to net wages, which is equivalent so long as hours worked are fixed and entrants have not reached the EITC cap. Our calculation is $-0.005 /(1.572 / 1.456-1)=-0.006$. For Eissa and Liebman the equivalent calculation is 0.019/(1.14/1.11-1).
} 
estimate that same $\$ 1000$ increase increases employment by 5 percentage points. Like our study, both Hotz et al. and Grogger use reduced form approaches, and cannot say whether their effects come from the increase in maximum benefits or the increase in subsidy rates. Nevertheless, we find that the Wisconsin third child supplement, which amounts to a \$1107 increase in the maximum benefit relative to two-child families, did not increase employment or hours worked at all.

Not only do we find the EITC effects to be zero, they are statistically significantly smaller than the point estimates of previous researchers. Ninety-five percent confidence intervals around our current employment estimate range from -5 percent to +4 percent. The confidence interval around our "worked last year" estimate range from -6 percent to +2 percent. This is for a comparable increase in maximum subsidies to prior studies, and a much larger increase in subsidy rates.

Our analysis compares the employment of single mothers with two and three children. We include measures of child care subsidies and welfare benefits because these are the two state policies that we particularly suspect would differentially affect families of different sizes, since child care costs generally increase with the number of children and since there is substantial state variation in the extent to which welfare benefits vary with family size. In other respects we expect that single-mother families with two and three children are more comparable than, for example, single women with and without children. A comparison of basic demographic characteristics of women by maternal status and number of children confirms this expectation (see appendix table A2). In this context it is noteworthy that when Meyer and Rosenbaum (2001) restrict their analysis to single mothers, relying on variation across states and number of 
children to identify the effects of taxes, the estimated effects of the EITC are smaller, and only significant for one of the two samples they use.

There are several reasons why our results might be expected to differ from previous estimates. We rely on a comparison of mothers with two and three children, and argue that there are less likely to be other unmeasured differences between these groups than, for example, between women with and without children. Meyer and Rosenbaum (2001) also find smaller (or no) effects when they compare mothers with different numbers of children. Thus, our results may correctly measure the general failure of the EITC to increase labor supply. On the other hand, the employment decisions of mothers with three children may be less sensitive to the EITC. It may be, for example, that the non-pecuniary costs and benefits of employment are more significant for mothers with larger families.

Following Neumark and Wascher (2001), we also estimated our model on subsamples of women with incomes less than 200 percent and less than 100 percent of the federal poverty line. Table 3 shows the coefficient estimates for the effect of the interaction of Wisconsin residence and having three children for each of these subsamples. Unlike Neumark and Wascher's results, we do not find larger employment elasticities for those with lower incomes. Rather, the coefficients all remain statistically insignificant and negative.

Table 3 also includes several alternative specifications. The first compares single mothers with one or two children to single mothers with three or more children. This almost doubles the sample size, while blurring somewhat the distinction between the two groups. The larger sample size does not yield a more statistically significant coefficient in any of the specifications, and the coefficients remain small and statistically insignificant. Second, we include in the comparison 
groups states that do have an EITC supplement (though none differentiate between two-child and three-child families). Again, the effects are small and insignificant.

One early reader suggested that a more similar control group would be the other states that do have EITC supplements -- just not supplements for third children. In the bottom panel of table 3 we estimate our basic specification for Wisconsin and the other 13 states (excluding DC) with EITC supplements. The measured effect of the EITC remains insignificant.

The last sensitivity analysis in table 3 explores sample selection. Throughout the analyses we have limited our sample to low income single mothers, the group most likely to be affected by the EITC. One might worry that we have therefore selected on an endogenous variable. Mothers who choose not to work have low incomes and low employment rates. At the bottom of table 3 we estimate the basic specifications from table 2 with women of all incomes with a high school education or less. None of the coefficients on the key regressor (the Wisconsin dummy interacted with the 3-child family dummy) is statistically significant or large, and the employment coefficients in columns (1) and (2) remain negative.

Finally, note that we use two measures of employment-current employment and worked last year. These are similar to the measures used by Meyer and Rosenbaum (2001), who point out that any employment in the last year should provide a sharper test of the theory, since the EITC has a theoretically unambiguous effect on ever working in a tax year, but an ambiguous effect on employment in any given week during the year. Despite the theoretical predictions, we estimate statistically insignificant effects using both definitions. One possible explanation is that annual employment rates are so high, particularly in Wisconsin, that it is difficult for the EITC to have a discernible effect. Meyer and Rosenbaum generally find larger effects for their annual 
measure, and when they restrict their analysis to single mothers, only find statistically significant effects using the annual measure. ${ }^{17}$

\section{Conclusion}

A key goal of the EITC is to redistribute income to working poor families. In practice, the EITC is an important income source for many vulnerable families, including many singlemother families making the transition from welfare to work under recent welfare reforms (Johnson 2000; Cancian et al. 2002). To many analysts, the EITC is preferable to other programs aimed at low-income families because it is tied to work. For families with a single worker earning low wages, the more hours worked, the greater their EITC. Thus, given its basic structure, the EITC unambiguously targets resources to low-income working families.

A less certain advantage of the EITC is its ability to increase labor supply. We use the 2000 Census of Population to examine the labor market consequences of the EITC by comparing the labor market behavior of eligible parents in Wisconsin, which supplements the federal EITC for families with three children, to the labor market behavior of otherwise similar parents in states that do not supplement the federal tax credit. We find no evidence of increased employment: for all of our samples and specifications the effect of the EITC on employment appears to be tiny, statistically insignificant, and negative.

Our conclusion that the EITC has no effect on labor supply departs from previous published results, despite the fact that we have a larger sample size (the 5-percent sample of the 2000 Census), identify the effect of the EITC using larger subsidy rate variation (Wisconsin's 43

\footnotetext{
${ }^{17}$ In our analysis both measures are for the same sample and from the same data source. Meyer and Rosenbaum (2001) use a measure of work in the last week from the larger Outgoing Rotation Group File of the CPS, and a measure of annual employment from the March CPS.
} 
percent third-child supplement), and use treatment and control groups that are more similar in other dimensions (low-income single women with 2 or 3 children). However, our findings are not altogether surprising. The program is complex, its subsidies are paid out long after the eligible labor is supplied, many workers are not even aware its existence, and jobs may not have flexible hours. In the end, we should not condemn the EITC's failure to stimulate participants' labor supply; rather, we should credit its ability to support low-income working families without deterring participants' labor supply. 


\section{References}

Bainbridge, J., Meyers, M. and Waldfogel J. 2002. "Child Care Policy Reform and the Employment of Single Mothers." Manuscript. Columbia University, New York.

Bertrand, Marianne, Esther Duflo, and Sendhil Mullainathan. 2002. "How Much Should We Trust Differences-in-Differences Estimation?" NBER Working Paper \#8841.

Cancian, Maria, Robert Haveman, Daniel Meyer, and Barbara Wolfe. 2002. "Before and After TANF: The Economic Well-Being of Women Leaving Welfare." Social Service Review 76(4): 603-641.

Council of Economic Advisers. 2001. Economic Report of the President. Washington, DC: GPO.

Dickert-Conlin, Stacy, Scott Houser, and John Karl Scholz. 1995. "The Earned Income Tax Credit and Transfer Programs: A Study of Labor Market and Program Participation." in James M. Poterba, ed. Tax Policy and the Economy 9: 1-50. NBER.

Ellwood, David T. 2000. "The Impact of the Earned Income Tax Credit and Social Policy Reforms on Work, Marriage, and Living Arrangements." National Tax Journal 53(4).

Eissa, Nada and Hilary Hoynes. 1998. "The Earned Income Tax Credit and the Labor Supply of Married Couples" NBER Working Paper No. 6856.

Eissa, Nada and Jeffrey B. Liebman. 1996. "Labor Supply Response to the Earned Income Tax Credit." Quarterly Journal of Economics (May): 605-637.

Grogger, Jeffrey. 2003a. "The Effects of Time Limits, the EITC, and Other Policy Changes on Welfare Use, Work, and Income Among Female-Headed Families," Review of Economics and Statistics 85(2): 394-408.

Grogger, Jeffrey. 2003b. "Welfare Transitions in the 1990s: The Economy, Welfare Policy, and the EITC." NBER working paper \#9472.

Hotz, V. Joseph and John Karl Scholz. 2001. "The Earned Income Tax Credit." Cambridge, MA: NBER Working Paper no. 8078, January.

Hotz, V. Joseph, Charles H. Mullen and John Karl Scholz. 2002. "The Earned Income Tax Credit and Labor Market Participation of Families on Welfare," working paper.

Johnson, Nicholas. 2000. A Hand Up: How State Earned Income Tax Credits Help Working Families Escape Poverty. Washington, DC: The Center on Budget and Policy Priorities. 
Meyer, Bruce D. and Dan T. Rosenbaum.2000. "Making Single Mothers Work: Recent Tax and Welfare Policy and Its Effects." National Tax Journal 53(4): 1027-1061.

Meyer, Bruce D. and Dan T. Rosenbaum. 2001. "Welfare, the Earned Income Tax Credit, and the Labor Supply of Single Mothers." Quarterly Journal of Economics (August) 1063-1114.

Neumark, David, and William Wascher. 2001, "Using the EITC to Increase Family Earnings: New Evidence and a Comparison with the Minimum Wage," National Tax Journal, pp. 281-317.

Ross Phillips, Katherin. 2001. "Who Knows About the Earned Income Tax Credit?" Urban Institute policy brief, No. B-27, January.

Scholz, John Karl. "The Earned Income Tax Credit: Participation, Compliance, and Antipoverty Effectiveness." National Tax Journal 47(1): 63-87, 1994. 
Table 1A. Employment Participation of Single Mothers (19-44 years old with 2 or 3 children and income less than $300 \%$ of federal poverty line)

\begin{tabular}{|c|c|c|c|c|c|c|}
\hline & \multicolumn{3}{|c|}{ Currently Employed } & \multicolumn{3}{|c|}{ Worked Last Year } \\
\hline & $\begin{array}{l}\text { Two Children } \\
\text { (1) }\end{array}$ & $\begin{array}{l}\text { Three Children } \\
\text { (2) }\end{array}$ & $\begin{array}{l}\text { Difference } \\
\text { (2) - (1) }\end{array}$ & $\begin{array}{l}\text { Two Children } \\
\text { (1) }\end{array}$ & $\begin{array}{l}\text { Three Children } \\
\text { (2) }\end{array}$ & $\begin{array}{l}\text { Difference } \\
\text { (2)-(1) }\end{array}$ \\
\hline \multirow[t]{3}{*}{ (1) Wisconsin } & 0.772 & 0.729 & $-0.043^{*}$ & 0.904 & 0.864 & $-0.040^{*}$ \\
\hline & $(0.011)$ & $(0.018)$ & $(0.021)$ & $(0.008)$ & $(0.014)$ & $(0.016)$ \\
\hline & $n=1400$ & $\mathrm{n}=595$ & & $n=1400$ & $\mathrm{n}=595$ & \\
\hline \multirow{3}{*}{$\begin{array}{l}\text { (2) States without } \\
\text { EITC supplements }\end{array}$} & 0.695 & 0.634 & $-0.060^{*}$ & 0.835 & 0.791 & $-0.044^{*}$ \\
\hline & $(0.002)$ & $(0.003)$ & $(0.003)$ & $(0.001)$ & $(0.002)$ & $(0.003)$ \\
\hline & $n=65,058$ & $n=28,968$ & & $n=65,058$ & $n=28,968$ & \\
\hline \multirow[t]{2}{*}{ Difference (1) - (2) } & $0.078^{\star}$ & $0.095^{\star}$ & 0.018 & $0.069^{*}$ & $0.072^{*}$ & 0.004 \\
\hline & $(0.011)$ & $(0.018)$ & $(0.022)$ & $(0.008)$ & $(0.014)$ & $(0.016)$ \\
\hline
\end{tabular}

*Difference of proportions is statistically significant at 5 percent.

Source: US Census of Population, 2000, Public Use Micro Sample (5 percent).

Notes:

- "Other states" are those without EITC supplements: AL, AR, AZ, CA, CT, DE, FL, GA, HI, ID, IN, KY, LA, ME, MO, MS, MT, NC, ND, NE, NH, NM, NV, OH, OK, PA, SC, SD, TN, TX, UT, VA, WA, and WV. 
Table 1B. Weekly Hours Worked by Single Mothers

(19-44 years old with 2 or 3 children and income less than $300 \%$ of federal poverty line)

\begin{tabular}{|c|c|c|c|}
\hline & $\begin{array}{c}\text { Two Children } \\
\text { (1) }\end{array}$ & $\begin{array}{c}\text { Three Children } \\
(2)\end{array}$ & $\begin{array}{c}\text { Difference } \\
(2)-(1)\end{array}$ \\
\hline (1) Wisconsin & $\begin{array}{c}37.89 \\
(10.24) \\
n=1265\end{array}$ & $\begin{array}{c}38.25 \\
(10.61) \\
n=514\end{array}$ & $\begin{array}{c}0.36 \\
(0.54)\end{array}$ \\
\hline (2) States without EITC supplements & $\begin{array}{c}38.04 \\
(9.76) \\
n=54306\end{array}$ & $\begin{array}{c}37.71 \\
(10.12) \\
n=22916\end{array}$ & $\begin{array}{l}-0.33^{*} \\
(0.08)\end{array}$ \\
\hline Difference (1) - (2) & $\begin{array}{l}-0.15 \\
(0.28)\end{array}$ & $\begin{array}{c}0.54 \\
(0.45)\end{array}$ & $\begin{array}{c}0.69 \\
(0.53)\end{array}$ \\
\hline
\end{tabular}

*Difference of means is statistically significant at 5 percent.

Source: : US Census of Population, 2000, Public Use Micro Sample (5 percent).

Notes:

- Includes only women working at the time of the Census.

- "Other states" are those without EITC supplements: AL, AR, AZ, CA, CT, DE, FL, GA, HI, ID, IN, KY, LA, ME, MO, MS, MT, NC, $\mathrm{ND}, \mathrm{NE}, \mathrm{NH}, \mathrm{NM}, \mathrm{NV}, \mathrm{OH}, \mathrm{OK}, \mathrm{PA}, \mathrm{SC}, \mathrm{SD}, \mathrm{TN}, \mathrm{TX}, \mathrm{UT}, \mathrm{VA}, \mathrm{WA}$, and WV. 
Table 2. Labor Supply and Participation Effects of the EITC

(Single mothers, 19-44 years old with 2 or 3 children and income less than $300 \%$ of federal poverty line)

\begin{tabular}{|c|c|c|c|c|c|c|}
\hline & \multirow[b]{2}{*}{$\begin{array}{c}\text { Means } \\
(1)\end{array}$} & \multicolumn{2}{|c|}{ Currently Employed } & \multicolumn{2}{|c|}{ Worked Last Year } & \multirow[b]{2}{*}{$\begin{array}{l}\text { Weekly Hours } \\
\text { Worked OLS } \\
(6)\end{array}$} \\
\hline & & $\begin{array}{c}\text { Probit } \\
\text { Coefficients } \\
(2) \\
\end{array}$ & $\begin{array}{l}\text { Marginal } \\
\text { Effects } \\
(3)\end{array}$ & $\begin{array}{c}\text { Probit } \\
\text { Coefficients } \\
(4)\end{array}$ & $\begin{array}{l}\text { Marginal } \\
\text { Effects } \\
(5)\end{array}$ & \\
\hline Wisconsin dummy & 0.021 & $\begin{array}{r}0.089^{*} \\
(0.040)\end{array}$ & 0.031 & $\begin{array}{r}0.177^{*} \\
(0.050)\end{array}$ & 0.040 & $\begin{array}{l}0.621^{\star} \\
(0.307)\end{array}$ \\
\hline 3 children dummy & 0.308 & $\begin{array}{l}-0.105^{\star} \\
(0.010)\end{array}$ & -0.037 & $\begin{array}{l}-0.102^{*} \\
(0.011)\end{array}$ & -0.026 & $\begin{array}{l}-0.286^{\star} \\
(0.080)\end{array}$ \\
\hline $\begin{array}{l}\text { Wisconsin } \times 3 \text { kids } \\
\text { Dummy }\end{array}$ & 0.006 & $\begin{array}{l}-0.015 \\
(0.068)\end{array}$ & -0.005 & $\begin{array}{l}-0.080 \\
(0.082)\end{array}$ & -0.021 & $\begin{array}{c}0.582 \\
(0.553)\end{array}$ \\
\hline Preschool age & 0.421 & $\begin{array}{l}-0.143 \\
(0.010)\end{array}$ & -0.051 & $\begin{array}{l}-0.179 * \\
(0.012)\end{array}$ & -0.045 & $\begin{array}{l}-0.559 * \\
(0.085)\end{array}$ \\
\hline Age of mother & $\begin{array}{c}33.1 \\
(6.2)\end{array}$ & $\begin{array}{c}0.116^{\star} \\
(0.007)\end{array}$ & 0.041 & $\begin{array}{c}0.066^{\star} \\
(0.008)\end{array}$ & 0.016 & $\begin{array}{c}0.553^{\star} \\
(0.060)\end{array}$ \\
\hline Age of mother squared & $\begin{array}{l}1136 \\
(406)\end{array}$ & $\begin{array}{l}-0.0017^{*} \\
(0.0001)\end{array}$ & -0.0006 & $\begin{array}{l}-0.0011^{*} \\
(0.0001)\end{array}$ & -0.0003 & $\begin{array}{l}-0.008^{*} \\
(0.001)\end{array}$ \\
\hline Completed high school & 0.757 & $\begin{array}{l}0.531^{*} \\
(0.010)\end{array}$ & 0.197 & $\begin{array}{l}0.551^{*} \\
(0.011)\end{array}$ & 0.155 & $\begin{array}{r}0.994^{*} \\
(0.094)\end{array}$ \\
\hline $\begin{array}{l}\text { Has associate or higher } \\
\text { Degree }\end{array}$ & 0.132 & $\begin{array}{r}0.350^{*} \\
(0.015)\end{array}$ & 0.115 & $\begin{array}{l}0.273^{\star} \\
(0.017)\end{array}$ & 0.061 & $\begin{array}{c}0.068 \\
(0.105)\end{array}$ \\
\hline $\begin{array}{l}\text { Has health problem that } \\
\text { disrupts work }\end{array}$ & 0.156 & $\begin{array}{c}0.020 \\
(0.012)\end{array}$ & 0.007 & $\begin{array}{l}-0.083^{*} \\
(0.013)\end{array}$ & -0.021 & $\begin{array}{l}-0.174^{\dagger} \\
(0.100)\end{array}$ \\
\hline
\end{tabular}

(continued) 
(Table 2, continued)

Hispanic origin

$$
\text { White }
$$

Other race

Immigrant

State unemployment level

State maximum AFDC

benefit (\$1000)

Federal child care spending per poor child (\$1000)

Head start and pre- $\mathrm{K}$ spending per young child (\$1000)

\begin{tabular}{|c|c|c|c|c|}
\hline Constant & & $\begin{array}{l}-1.59^{\star} \\
(0.12) \\
\end{array}$ & $\begin{array}{c}0.195 \\
(0.135) \\
\end{array}$ & $\begin{array}{c}31.51^{*} \\
(1.03) \\
\end{array}$ \\
\hline $\mathrm{N}$ & 96021 & 96021 & 96021 & 79001 \\
\hline $\mathrm{R}^{2}$ & & 0.063 & 0.055 & 0.011 \\
\hline
\end{tabular}

Standard errors in parenthesis (robust standard error for (2) through (6)).

* Statistically significant at 5\%. + Statistically significant at $10 \%$.

${ }^{A}$ Column 6 includes only working women.
Currently Employed

Probit Marginal

Probit

(2)

Worked Last Year

Probit Marginal Weekly Hours

Effects

Coefficients

(4)

Effects

(5)

0.022

$0.616^{*}$

(0.019)

(0.021)

(0.162)

$0.252^{\star}$
$(0.010)$

0.089

$0.117^{*}$

0.029

$-0.039$

0.068

0.024

(0.011)

(0.079)

(0.121)

$-0.016$

(0.024)

$-0.004$

0.095

$-0.088^{*}$

$-0.032$

$-0.009$

(0.018)

$-0.002$

(0.184)

(0.016)

$-0.024$

$-0.103^{*}$

(0.009)

$-0.025$

(0.141)

(0.765)

(0.007)

$-0.033$

$-0.178^{*}$

(0.042)

$-0.044$

$-0.433^{*}$

(0.064)

(145.5)

(0.037)

$-0.021$

(0.021)

$-0.005$

$-4.294^{*}$

(0.309)

738.7
$(305.7)$

(0.019)

$-0.143^{*}$

(0.153)

245.2

$-0.080$

$-0.028$

(0.058)

$-0.036$

$-0.270$

(0.410)

$(0.052)$

(0.058)

0.011 
Table 3. Alternative Samples

Estimated Coefficients on Wisconsin

x 3 Children Interaction

$\begin{array}{ccc}\text { Currently } & \text { Worked Last } & \text { Weekly Hours } \\ \text { Employed } & \text { Year } & \text { Worked OLS } \\ \text { Probit } & \text { Probit } & \text { Regression } \\ (1) & (2) & (3)\end{array}$

Sample: single mother age 19-44, with 2 or 3 children whose income:

From Table 2.

(Less than $300 \%$ of federal

poverty line).

Less than $200 \%$ of federal poverty line.

Less than $100 \%$ percent of federal poverty line.
$-0.015$

$(0.068)$

$[-0.005]$

$\mathrm{n}=96021$

$-0.001$

$(0.074)$

$[-0.0004]$

$\mathrm{n}=80352$

$-0.086$

(0.101)

[-0.034]

$\mathrm{n}=45618$
$-0.080$

(0.082)

[-0.021]

$\mathrm{n}=96021$

$-0.051$

(0.087)

[-0.015]

$\mathrm{n}=80352$

$-0.084$

(0.109)

[-0.031]

$n=45618$
0.582

(0.553)

$\mathrm{n}=79001$

0.508

(0.633)

$\mathrm{n}=63694$

0.858

$n=30582$

Sample: single mothers 19-44 years old, and:

Income less than $300 \%$ of

federal poverty line, with

children

Income less than $300 \%$ of

federal poverty line, with 2 or 3

children, including other states

with EITC supplements
$-0.046$

$(0.062)$

$[-0.016]$

$\mathrm{n}=175709$

$-0.027$

(0.068)

[-0.010]

$\mathrm{n}=125824$
$-0.082$

(0.074)

$[-0.020]$

$\mathrm{n}=175709$

$-0.078$

$(0.082)$

[-0.020]

$\mathrm{n}=125824$
0.434

$(0.507)$

$n=146983$

0.553

$(0.552)$

$n=102891$

Sample: single mother age 19-44, with 2 or 3 children and:

Income less than $300 \%$ of federal poverty line, in a state with an EITC supplement ${ }^{\mathrm{B}}$

With high school education or lower

-0.063
$(0.070)$
$[-0.023]$
$n=31798$
-0.036
$(0.087)$
$[-0.014]$
$n=59688$

$-0.065$

$(0.084)$

[-0.017]

$\mathrm{n}=31798$

$-0.040$

$(0.102)$

[-0.012]

$\mathrm{n}=59688$
0.431

(0.566)

25669

0.446

(0.708)

$\mathrm{n}=46504$

† Significant at 10\% level ,** significant at 5\% level. Robust standard errors in parentheses (). Marginal effects for probit models in square brackets [].

A. Column (3) regression is conditional on positive hours worked.

B. States with EITC supplements are CO, IL, IA, KS, MA, MD, ME, MN, NJ, NY, OR, RI, VT, and WI. Washington DC also has an EITC supplement, but is excluded here. 
Appendix Table A1. Sample Construction

$\begin{array}{ll}\text { Sample Criterion } & \text { Observations }\end{array}$

Single female household heads $\quad 1,471,967$

Age 19-44

558,896

Exclude DC and WY

555,338

With income less than 300 percent of the federal poverty line 390,657

Living in Wisconsin or a state without an EITC supplement

296,874

With two or three dependent children

96,021

Source: 5-Percent Public Use Microsample (PUMS) of the 2000 Census of Population. 
Appendix Table A2. Demographic characteristics of household head

(Sample: female household head, 19 to 44 years old, income $<=300 \%$ of poverty threshold)

\begin{tabular}{|c|c|c|c|c|c|}
\hline & $\begin{array}{l}\text { With no children } \\
\text { in all states } \\
(1)\end{array}$ & $\begin{array}{c}\text { With } 2 \text { children } \\
\text { in Wisconsin } \\
(2)\end{array}$ & $\begin{array}{c}\text { With } 3 \text { children } \\
\text { in Wisconsin } \\
(3)\end{array}$ & $\begin{array}{l}\text { With } 2 \text { children } \\
\text { in states with } \\
\text { no EITC } \\
\text { supplement } \\
(4)\end{array}$ & $\begin{array}{l}\text { With } 3 \text { children } \\
\text { in states with } \\
\text { no EITC } \\
\text { supplement } \\
\text { (5) }\end{array}$ \\
\hline Age & $\begin{array}{c}30.42 \\
(8.13)\end{array}$ & $\begin{array}{c}33.42 \\
(6.32)\end{array}$ & $\begin{array}{c}33.98 \\
(5.38)\end{array}$ & $\begin{array}{c}33.31 \\
(6.43)\end{array}$ & $\begin{array}{l}33.07 \\
(5.78)\end{array}$ \\
\hline High school degree & 0.88 & 0.85 & 0.81 & 0.78 & 0.71 \\
\hline $\begin{array}{l}\text { Higher education } \\
\text { degree }\end{array}$ & 0.304 & 0.171 & 0.165 & 0.138 & 0.115 \\
\hline Unhealthy & 0.141 & 0.118 & 0.136 & 0.155 & 0.160 \\
\hline Hispanic origin & 0.041 & 0.021 & 0.040 & 0.077 & 0.103 \\
\hline Black & 0.169 & 0.175 & 0.226 & 0.321 & 0.376 \\
\hline White & 0.719 & 0.777 & 0.697 & 0.555 & 0.469 \\
\hline Other & 0.071 & 0.044 & 0.069 & 0.047 & 0.051 \\
\hline Immigrant & 0.104 & 0.029 & 0.035 & 0.098 & 0.124 \\
\hline $\begin{array}{l}\text { Mother's } 1999 \\
\text { earnings }(\$)^{A}\end{array}$ & $\begin{array}{l}13887 \\
(7454)\end{array}$ & $\begin{array}{l}17242 \\
(9347)\end{array}$ & $\begin{array}{c}17514 \\
(10666)\end{array}$ & $\begin{array}{l}16137 \\
(9657)\end{array}$ & $\begin{array}{l}15458 \\
(10422)\end{array}$ \\
\hline Observations & 142,373 & 1400 & 595 & 65,058 & 28,968 \\
\hline
\end{tabular}

Source: 5-Percent Public Use Microsample (PUMS) of the 2000 Census of Population.

A. Mother's 1999 earnings conditional on working. 
Figure 1. Simple labor supply effects of the EITC.

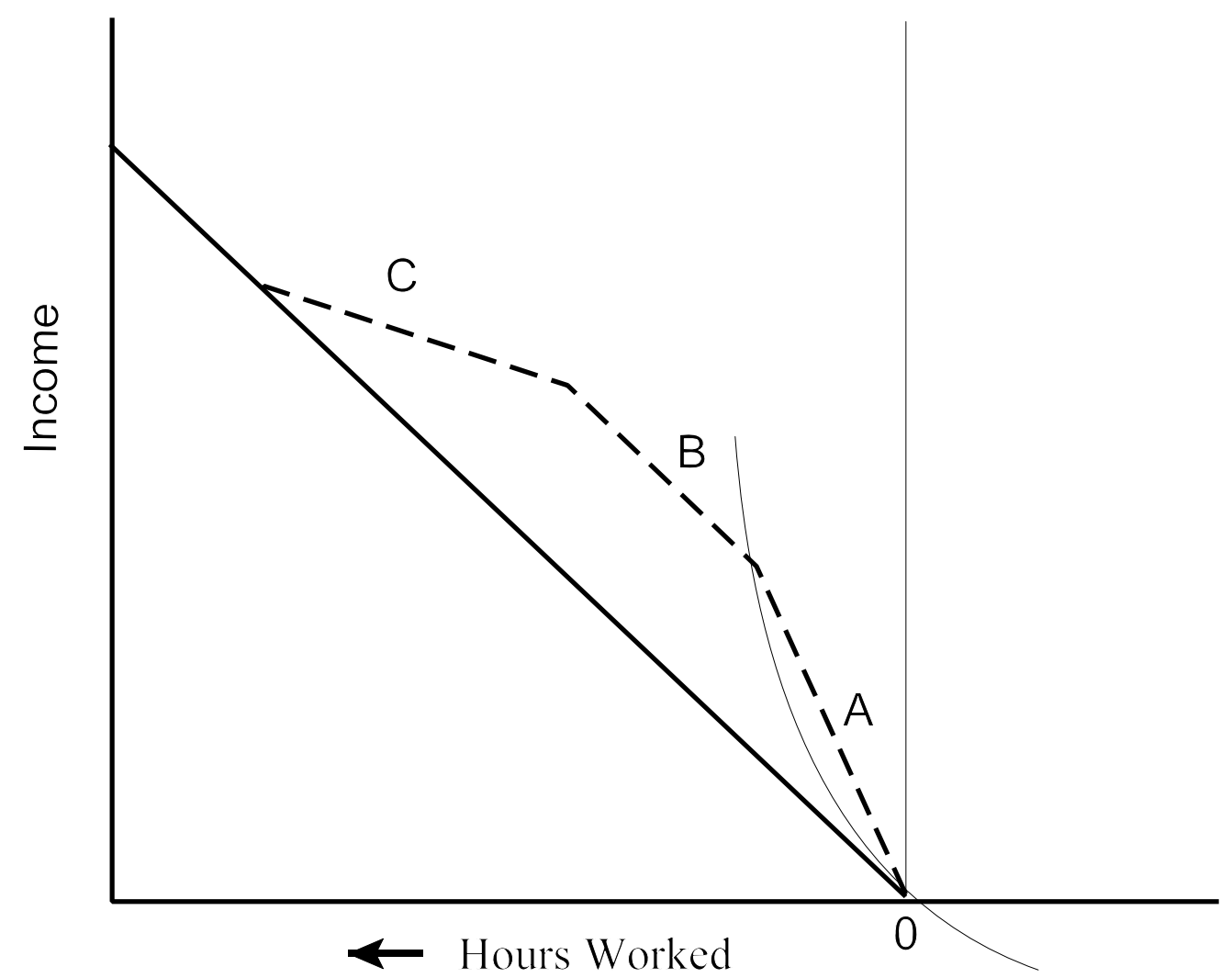


Figure 2. Labor supply effects of the EITC with fixed costs.

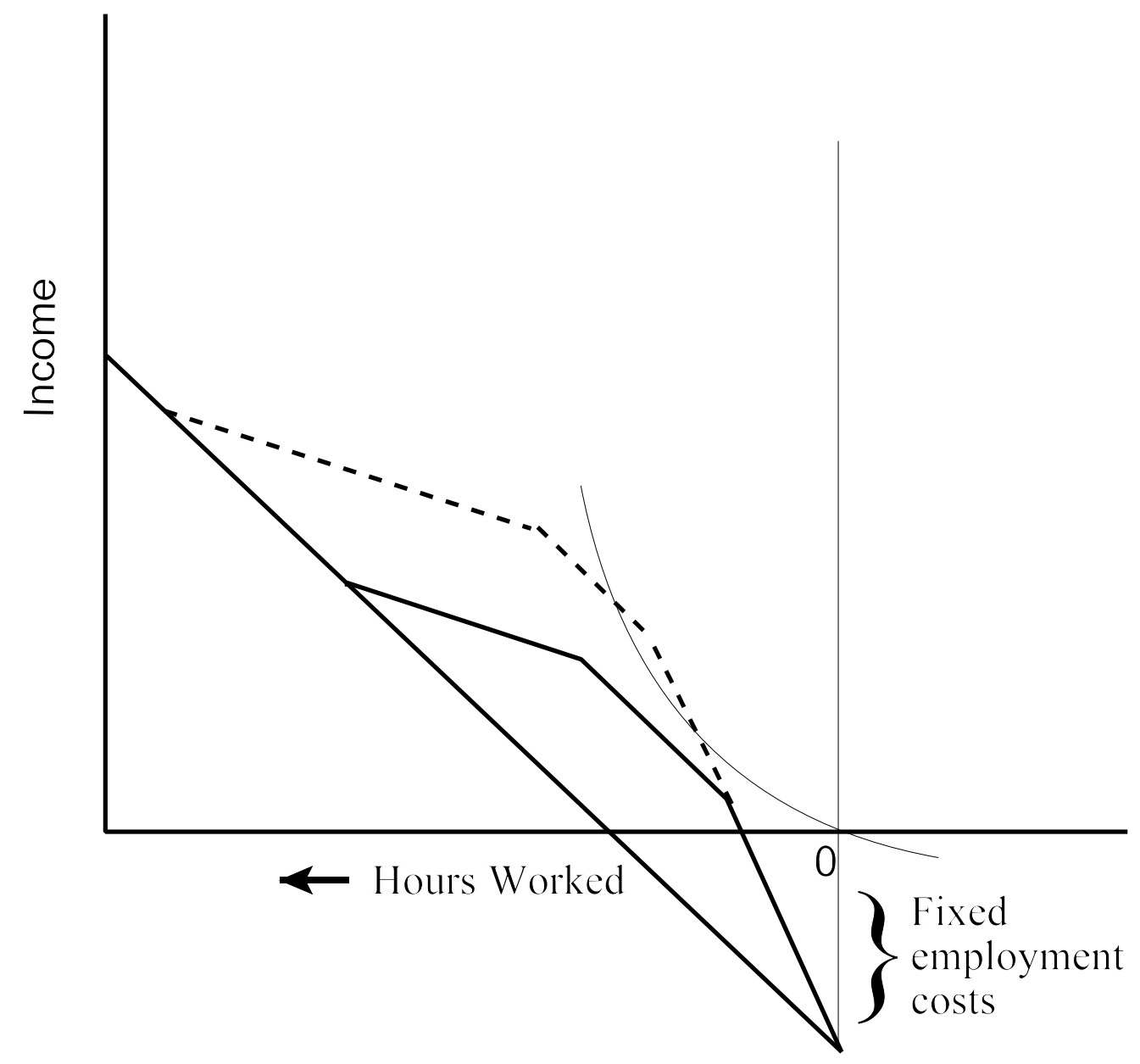


Figure 3. Actual federal EITC and WI 3rd child supplement

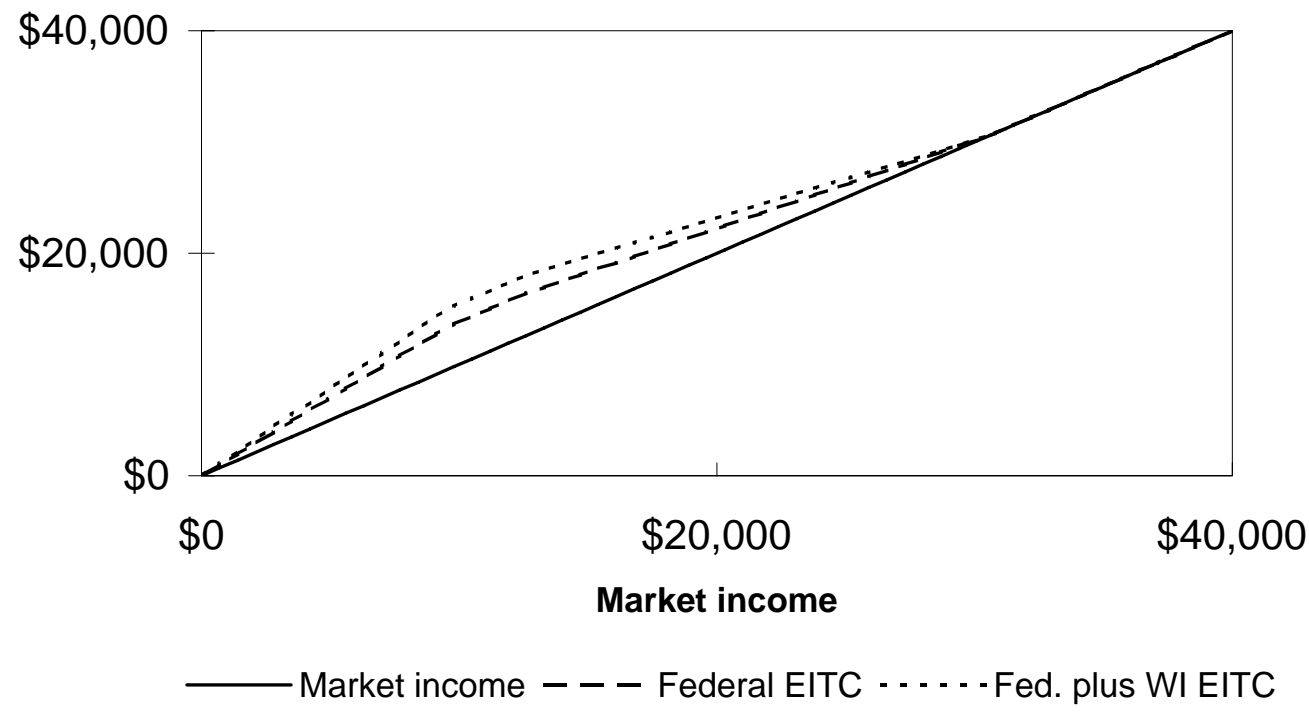

